\title{
The Juridical Study Claims for Cancellation of Insurance Rights Auction Execution
}

\author{
Putri Qoriyati Aeny") and Arpangi ${ }^{* *}$ \\ *) Faculty of Law, Universitas Islam Sultan Agung (UNISSULA) Semarang, E-mail: \\ putriaeny4@gmail.com \\ ${ }^{* *}$ Faculty of Law, Universitas Islam Sultan Agung (UNISSULA) Semarang, E-mail: \\ arpangi@unissula.ac.id
}

\begin{abstract}
This study aims to examine the issue of the lawsuit for canceling the execution of credit guarantee auctions that are burdened with mortgage rights in the Boyolali District Court Decision Number 64/Pdt.G/2018/PN Byl. Reviewing Judges' Considerations in Deciding Cases on Claims for Cancellation of Execution of Mortgage Auctions. Reviewing the Legal Consequences of Lawsuits for Cancellation of Execution of Mortgage Auctions. This research is a normative juridical research. This research focuses on document or library research which essentially looks for theories, views that have correlation and are relevant to the problems to be studied. The results of the study concluded that the lawsuit for the cancellation of the execution of the credit guarantee auction that was burdened with mortgage rights in the Boyolali District Court Decision Number: 64/Pdt. G/2018/PN Byl, which starts with the provision of Local Credit Facilities (Current Accounts) with a credit limit not exceeding IDR 1,700,000,000.00 (one billion seven hundred million rupiah), based on Credit Agreement No. 125/PK/KRED/SLA/2008 dated October 13, 2008, and has been amended and updated several times, most recently by Amendment to Credit Agreement No. 145/AD/KRED/SLA/2015 dated October 6, 2015, and has been extended several times, most recently with the Notification of Extension of Period No. 145/AD/KRED/SLA/2015. 00118/SLA/SPPJ/2017 dated October 12, 2017. However, during the credit agreement period, the Plaintiff defaulted because he did not make installments every month, so Defendant I had given warning letters 3 times, therefore Defendant I through Defendant II carried out an auction execution of the object of credit guarantee that had been registered with the Mortgage Rights. The judge's consideration in deciding the lawsuit for the cancellation of the execution of the mortgage auction that was burdened with Mortgage was based on the exception of Defendant I and the evidence presented at the trial, which showed that the auction of the execution of the mortgage on the Collateral Object had been carried out in accordance with Article 22 PMK No. 27/PMK.06/2016, namely by the Class I Auction Officer at the Surakarta KPKNL is legally valid. The legal consequences of the Boyolali District Court Decision
\end{abstract}


Number: 64/Pdt. G/2018/PN Byl that the auction of Mortgage Execution conducted by Defendant I and Defendant II of the collateral that is guaranteed by the credit agreement through the Surakarta State Property and Auction Service Intermediary Office (KPKNL) is legal according to law. The legal consequence for the Plaintiff is the obligation to pay court fees.

Keywords: Auction Cancellation Lawsuit; Mortgage Rights; Execution.

\section{Introduction}

The function of the guarantee is to give the bank the right and power to get repayment with the collateral, if the debtor fails to repay the debt at the time specified in the agreement. The implementation of the provision of collateral and the binding of collateral must be in accordance with the provisions of the applicable laws so that it can provide protection through a guarantee rights institution and provide legal certainty for all interested parties. The execution of the debtor's guarantee is a second way out which is the creditor's right to obtain funds that have been distributed to the debtor.

Salim HS argues that: "A guarantee is something given to a creditor to create confidence that the debtor will fulfill obligations that can be valued in money arising from an engagement." 1 The safest credit guarantee is a material guarantee. In accordance with the nature of material rights, these rights are special in that the collateral object is devoted to the interests of the creditor, and material rights also follow the object, so that it can be defended from anyone.

The Law of the Republic of Indonesia Number 4 of 1996 concerning Mortgage Rights on Land and Objects Related to Land, provides a position that is prioritized for creditors holding Mortgage Rights over other creditors. If the debtor is in default, the object of the mortgage by the creditor holding the mortgage is sold through a public auction according to the method specified in the applicable laws and regulations and the creditor who holds the mortgage has the right to take all or part of the proceeds for the settlement of his receivables guaranteed by the mortgage with precedence over other creditors.

Execution of the object of collateral is the exercise of the rights of the creditor holding the collateral right to the object of the guarantee in the event of a denial by the debtor by selling the object of the object of collateral to pay off the debt. Execution is usually carried out if there are receivables that have been collected (opeisbaar) and the debtor does not fulfill its performance voluntarily, here the

${ }^{1}$ Salim HS, 2017, Perkembangan Hukum Jaminan Di Indonesia, Raja Grafindo Persada, Jakarta, p. 22 
creditor can demand the fulfillment of his receivables or the right of execution of the object of the material guarantee that he has agreed upon.

The right to fulfill the creditor's rights is carried out by selling the object of the collateral, and the proceeds are used as repayment of the creditor's receivables. Article 6 and Article 20 of Act No. 4 of 1996 concerning Mortgage on Land and Objects Related to Land gives the right to sell the object of Mortgage for reasons of breach of contract, if the debtor is in default, the holder of the mortgage (creditor) has the right to sell the object. Mortgage rights, both based on court decisions and on their own power, the meaning of selling the mortgage object for reasons of default is the same as executing the mortgage object.

Act No. 4 of 1996 concerning Mortgage on Land and Objects Related to Land provides provisions for the convenience and certainty of the execution of Mortgage Rights. However, the provisions of Article 14 of the Regulation of the Minister of Finance of the Republic of Indonesia Number 27/PMK.06/2016 concerning Auction Implementation Guidelines ("PMK Auction Implementation Guidelines") states that the execution auction according to Article 6 of Act No. 4 of 1996 concerning Mortgage on Land Along with Objects Related to Land, it cannot be carried out if there is a lawsuit before the auction against the object of Mortgage from other parties other than the debtor/executed, the husband or wife of the debtor/executed related to ownership.

In exercising the bank's right to the execution of the mortgage object, sometimes the bank faces various problems that can cause the bank's right to sell the mortgage object to be delayed. One of the obstacles faced by banks to execute the object of mortgage is a lawsuit made by the debtor to the bank asking for a delay in the execution of the object of mortgage. This is due to the possibility that there are some debtors who are naughty or feel that the creditor's decision is unfair in carrying out the execution of their land. In this case the creditor really needs legal protection, in order to overcome some of the problems that will arise in the credit agreement from the creditor to the debtor.

Banks as creditors holding mortgage rights have a special position compared to other creditors. This means that when there is a real default from the debtor, the creditor holding the first mortgage has the right to make a sale through a public auction of the object of the debtor's collateral. Sales through auctions of collateral objects must go through the procedural laws and regulations (UUHT). According to ST. Remy Sjahdeini in Tri Kurniawan asserts that according to Article 6 of the UUHT, if the debtor has a pledge, the holder of the first mortgage has 
the right to sell the object of the mortgage on his own power through a public auction and take repayment of his receivables from the proceeds of the sale. ${ }^{2}$

One option that can be executed is in the form of parate execution as stated in Article 6 of the UUHT. Parate execution in mortgage is an execution without interference from the court but directly asks the State auction office to conduct an auction for the object of mortgage guarantee, to make a decision on the debtor's debt, as happened in the case of auction of collateral goods in Boyolali District Court Decision Number 64/Pdt .G/2018/PN Byl.

This case began with the debtor and creditor entering into a Working Capital Credit Agreement (KMK), namely H. Soejono and Sri Wahyuni as Plaintiffs against PT Bank Central Asia, Tbk Salatiga Branch. 1482, Candi Village, Ampel District, Boyolali Regency, Central Java Province, area + $427 \mathrm{M} 2$ (four hundred and twenty-seven square meters). Over time, the debtor has defaulted by not making installment payments, even though a warning letter has been submitted 3 (three) times, the fact is that the Plaintiff as the debtor still does not pay the debt to the Defendant as the creditor, so it is clearly proven that the Plaintiff has no good faith to settle the arrears owed to the Defendant.

Based on the foregoing, the creditor submits an application for an execution auction of the disputed object to the State Property and Auction Service Office (KPKNL) based on Article 6 of Act No. 4 of 1996 concerning Mortgage Rights on Land and Objects Related to Land, However, when the execution auction is going to be held, the debtor sues the court on the grounds that the creditor has committed an unlawful act, namely, the debtor assumes that the creditor conducts an execution auction of the object of dispute not through the District Court, thus the creditor feels aggrieved.

\section{Research Methods}

This research method uses a normative juridical approach, data collection using literature study. The specifications used in this study are analytical descriptive which are intended to provide as accurate data as possible about a condition or other symptom and it is hoped that this research can provide a clear description of the Judge's Considerations in Deciding the Case of Cancellation of Execution of Mortgage Auction in Boyolali District Court Decision Number 64 /Pdt.G/2018/PN Byl. The data analysis method was carried out qualitatively and then presented descriptively. Research problems in analysis with legal certainty theory.

\footnotetext{
${ }^{2}$ Tri Kurniawan, "Kajian Yuridis Terhadap Parate Eksekusi Objek Jaminan dalam Perjanjian Hak Tanggungan," Jurnal Ilmu Hukum Legal Opinion, Vol.4, (2016), p. 3
} 


\section{Results and Discussion}

\subsection{Situation of Lawsuit for Cancellation of Execution of Credit Guarantee Auction Encumbered with Mortgage in Boyolali District Court Decision Number 64/Pdt.G/2018/PN Byl}

The Plaintiff is the legal holder of the land and house as stated in the Land Book No. Hak Milik. 1482, Candi Village, Ampel District, Boyolali Regency, Central Java Province, area $+427 \mathrm{M} 2$ (four hundred and twenty-seven square meters). $8949 / 1995$ was recorded in the name of the right holder Soejono Bin Mintodiharjo. That the Book of Ownership Land No. 1482, Candi Village, Ampel District, Boyolali Regency, Central Java Province, area of +427 M2 (four hundred and twenty-seven square meters). 8949/1995 was registered in the name of the right holder Soejono Bin Mintodiharjo, as collateral for the debt by the Plaintiffs at PT BANK CENTRAL ASIA, Tbk. Salatiga Branch.

The Plaintiffs have fulfilled their monthly obligations, namely paying the interest of IDR 5,000,000.00 (five million rupiah) determined by PT BANK CENTRAL ASIA, Tbk. Salatiga Branch. In November 2018 Plaintiff I was summoned and met with employees of PT BANK CENTRAL ASIA, Tbk. Salatiga branch, whose name is and usually called Mrs. ASIH, she warned that Plaintiff I to deposit/install capital in December 2018 of IDR 500,000,000.00 ( five hundred million rupiah). On the warning from Mrs. ASIH, Plaintiff I agreed to be paid in installments as determined, namely IDR 500,000,000.00 (five hundred million rupiah) in midDecember 2018.

That on the advice of Mrs. ASIH, until the lawsuit was filed in the Boyolali District Court, it was not yet due in mid-2018, it turned out that the Plaintiffs received a notification from PT BALAI LELANG TUNJUNGAN, Jl. Woltermonginsidi KM.1 No.1 RT.01 RW. 05 Banjardowo Village, Genuk District, Semarang City, regarding the Pre Auction Process number 0048/S.BLT/SMG/X/2018 dated 16 October 2018.

In the opinion of the Plaintiffs, Defendant II is not authorized to carry out the Notification of the Pre Auction Process, because the auction has been regulated in the Regulation of the Minister of Finance of the Republic of Indonesia Number 106/PMK.06/2013 concerning Amendments to the Regulation of the Minister of Finance Number 93/Pmk.06/2010 concerning Article 19 of the Auction Implementation Instructions has stipulated that the place for the auction must be in the working area or the position of the Class II Auction Officer where the goods are located. In this case, the object of the guarantee is in the Boyolali Regency area. Therefore, PT Balai Auction Tunjungan, is not authorized to make a notification of the Pre Auction Process, and is obliged to refuse bidding applications that are not within its authority. 
Defendant III was involved in this case with the intention that the object of the dispute over the land belonging to the Plaintiffs should not be transferred to another party before this case has permanent legal force, this is because there has been a notification of the pre-auction process. Therefore, to guarantee the claim for compensation filed by the Plaintiffs so that the object of the dispute is not transferred to another party, please place a confiscation of collateral (Conservatoir Beslag) on the land of the object of dispute. Whereas because the Plaintiffs' claim is based on legal facts and authentic evidence and cannot be denied, this decision can be implemented first even though other legal remedies are possible.

Based on Article 1365 of the Civil Code, "Every act against the law that causes harm to others, requires other people because of the fault it compensated for the losses incurred" that based on the Article, because the actions of the Defendants have harmed the Plaintiffs and are against the law, the Defendants should jointly and severally pay compensation in cash and cash to the Plaintiffs in the amount of IDR 2,000,000,000.00 (two billion rupiah) with the following details: a. Material compensation to pay for the services of a lawyer IDR $500,000,000.00$, b. Immaterial compensation IDR 1,500,000,000.00. Amount IDR 2,000,000,000.00 (two billion rupiah).

Based on all the descriptions and positas mentioned above, then with all humility the Plaintiffs request that before the Head of the District Court in Boyolali please examine the Plaintiffs' claims before the Boyolali District Court trial and subsequently render the fairest decision as follows:

a. Granted the claim of the Plaintiffs in their entirety.

b. To declare that Defendant I, Defendant II and Defendant III have committed acts against the law

c. Declare a valid and valuable security confiscation (Beslag Conservatory) to Land with Ownership No. 1482, Candi Village, Ampel District, Boyolali Regency, Central Java Province, area $+427 \mathrm{M} 2$ (four hundred and twentyseven square meters) $8949 / 1995$ was recorded in the name of the right holder Soejono Bin Mintodiharjo, which was carried out by the bailiff of the Boyolali District Court.

d. Sentencing the Defendants to postpone the auction of the collateral for the debt on the Land of Ownership No. 1482, Candi Village, Ampel District, Boyolali Regency, Central Java Province, area + 427 M2 (four hundred and twenty-seven square meters). 8949/1995 registered in the name of the right holder Soejono Bin Mintodiharjo, to PT Bank Central Asia, until the decision of this case has permanent legal force. 
e. Sentencing the Defendants jointly and severally to pay compensation in cash and cash to the Plaintiffs in the amount of IDR 2,000,000,000.00 (two billion rupiah) with the following details:

1) Material compensation to pay for the services of a lawyer IDR 500,000,000.00

2) Immaterial compensation of IDR $1,500,000,000.00$ Amount IDR 2,000,000,000.00 (two billion rupiah).

f. Stating that the decision in this case can be executed first (uit voerbaar bij voorrad) despite the possibility of an appeal, cassation or verzet or other legal remedies from the Defendant.

g. Punish the Defendant to pay all costs incurred in this case.

Or:

Provide another decision which the Boyolali District Court considers fair, proper and appropriate, in a good trial, based on Pancasila and the laws in force in our country.

Based on the results of the analysis, it can be explained that the lawsuit for the cancellation of the execution of the credit guarantee auction that is burdened with mortgage rights in the Boyolali District Court Decision Number: 64/Pdt.G/2018/PN Byl, namely starting from the provision of Local Credit Facilities (Newspaper Accounts) with a total credit limit does not exceed IDR $1,700,000,000.00$ (one billion seven hundred million rupiah), based on Credit Agreement No. 125/PK/KRED/SLA/2008 dated October 13, 2008 which was made under hand with sufficient stamp duty, and has been amended and updated several times, most recently by Amendment to Credit Agreement No. 145/AD/KRED/SLA/2015 dated October 6, 2015 which was made under hand with sufficient stamp duty, and has been extended several times, most recently by Notification Letter of Extension of Period No.

The Plaintiffs during the credit agreement period, the Plaintiffs defaulted because they did not make monthly installments, so that Defendant I had given warning letters 3 times, but did not receive a response from the Plaintiffs, therefore Defendant I through Defendant II carried out an auction execution of the object of credit guarantee which has been registered with the Mortgage Rights.

3.2. Judge's Consideration in Deciding the Case for Cancellation of Execution of Credit Guarantee Auctions Encumbered with Mortgage in Boyolali District Court Decision Number 64/Pdt.G/2018/PN Byl 
Based on the results of the analysis, it can be explained that the Boyolali District Court judge in deciding the case had considered the statements of the Plaintiff and Defendant, which was adjusted to the evidence submitted by the Plaintiff and Defendant. The Panel of Judges concluded that the Plaintiff did not have good faith to pay off his debt, so Defendant I warned the Plaintiff to be able to pay off his debt by sending Warning Letter I (First) dated March 12, 2018 and Warning Letter III (Third) dated May 2 2018, then issued notification letter of pre auction process Number 0048/S.BLT/SMG/X/2018 dated October 16, 2018.

The Panel of Judges is of the opinion that the auction of the execution of mortgage rights on the Collateral Object conducted by Defendant I and Defendant II has been carried out in accordance with the provisions of Article 22 PMK No. 27/PMK.06/2016, namely by the Class I Auction Officer at KPKNL Surakarta, as evidenced by the Copy of Minutes of Auction No. 90/38/2019 dated February 12, 2019 published by KPKNL Surakarta.

\subsection{Legal Consequences of Lawsuit for Cancellation of Execution of Credit Guarantee Auctions Encumbered with Mortgage on Boyolali District Court Decision Number 64/Pdt.G/2018/PN Byl}

The legal consequences of the Boyolali District Court Decision Number: 64/Pdt.G/2018/PN Byl which rejected the plaintiff's claim, the legal consequences for the parties are as follows:

\section{a. For Defendant I and Defendant II}

The legal consequence of the Boyolali District Court Decision Number: 64/Pdt.G/2018/PN Byl which rejected the plaintiff's claim, the auction of the execution of mortgage rights against the Collateral Object has been carried out in accordance with the provisions of Article 22 PMK No. 27/PMK.06/2016, namely by the Class I Auction Officer at KPKNL Surakarta, as evidenced by the Copy of Minutes of Auction No. 90/38/2019 dated February 12, 2019 published by KPKNL Surakarta. As for Attachment II to the Regulation of the Minister of Finance of the Republic of Indonesia Number 263/PMK.01/2016 concerning Amendments to the Regulation of the Minister of Finance Number 170/PMK.01/2012 concerning the Organization and Work Procedures of Vertical Agencies of the Directorate General of State Assets ("PMK No. 263/ PMK.01/2016"), that the work area of the Surakata KPKNL includes Surakarta City, Boyolali Regency, Karanganyar Regency, Klaten Regency,

Considering the location of the Collateral Object is located in Boyolali Regency, the execution auction of the Collateral Object conducted through the Surakata KPKNL is correct and appropriate according to the division of 
the KPKNL working area as regulated in PMK No. 263/PMK.01/2016. Thus it is proven that the auction has been carried out in accordance with the provisions of Article 22 of the Regulation of the Minister of Finance PMK No. 27/PMK.06/2016, which states that: "The place for the auction must be within the KPKNL working area or the Class II Auction Officer position where the goods are located." Therefore, the auction is valid and cannot be canceled legally, based on the provisions of Article 4 PMK No. 27/PMK.06/2016 which states: "The auction which has been carried out in accordance with the applicable provisions, cannot be cancelled."

\section{b. For Plaintiffs}

The legal consequences for the plaintiff against the decision of the Boyolali District Court Number: 64/Pdt.G/2018/PN Byl which rejected the plaintiff's claim, that the Plaintiff has an obligation to pay court fees in the amount of IDR3,451,000.00 (three million four hundred five twenty one thousand rupiah).

Based on the results of the analysis, it is shown that the Boyolali District Court Judge rejected the Plaintiffs' lawsuit in its entirety, so that it had a legal impact on the Plaintiffs and Defendants. The legal consequence for the plaintiff is to pay court fees in the amount of IDR3,451,000.00 (three million four hundred fiftyone thousand rupiah). Meanwhile, the legal consequence for the Defendant is the implementation of an auction for the guarantee of the debt on the Land of Ownership No. 1482, Candi Village, Ampel District, Boyolali Regency, Central Java Province, area $+427 \mathrm{M} 2$ (four hundred and twenty-seven square meters). $8949 / 1995$ registered in the name of the right holder Soejono Bin Mintodiharjo, to PT Bank Central Asia is legal according to law. This is considering the location of the Collateral Object is located in Boyolali Regency, then the execution auction of the Collateral Object conducted through the Surakata KPKNL is correct and appropriate according to the division of the KPKNL working area as regulated in PMK No. 263/PMK.01/2016.

The auction has been carried out in accordance with the provisions of Article 22 Regulation of the Minister of Finance PMK No. 27/PMK.06/2016, which states that: "The place for the auction must be within the KPKNL working area or the Class II Auction Officer position where the goods are located." Therefore, the auction is valid and cannot be canceled legally, based on the provisions of Article 4 PMK No. 27/PMK.06/2016 which states that: "The auction which has been carried out in accordance with the applicable provisions cannot be cancelled."

\section{Closing}


There is a lawsuit for the cancellation of the execution of credit guarantee auctions that are burdened with mortgage rights in the Boyolali District Court Decision Number: 64/Pdt.G/2018/PN Byl, which begins with the provision of Local Credit Facilities (Current Accounts) with the amount of the credit limit not exceeding IDR 1,700,000,000.00 (one billion seven hundred million rupiah), based on Credit Agreement No. 125/PK/KRED/SLA/2008 dated October 13, 2008 which was made under hand with sufficient stamp duty, and has been amended and updated several times, most recently by Amendment to Credit Agreement No. 145/AD/KRED/SLA/2015 dated October 6, 2015 which was made under hand with sufficient stamp duty, and has been extended several times, most recently by Notification Letter of Extension of Period No. 00118/SLA/SPPJ/2017 dated October 12, 2017. However, during the credit agreement period, The Plaintiff defaulted because it did not make installments every month, so Defendant I had given warning letters 3 times, but did not get a response from the Plaintiff, therefore Defendant I through Defendant II carried out an auction execution of the object of credit guarantee that had been registered with Mortgage. The judge's consideration in deciding the lawsuit for the cancellation of the execution of the credit guarantee auction that was burdened with Mortgage in the Boyolali District Court Decision Number: 64/Pdt.G/2018/PN Byl was based on the exception of Defendant I and the evidence presented at trial, which showed that the auction was conducted the execution of the mortgage on the Collateral Object has been carried out in accordance with the provisions of Article 22 PMK No. 27/PMK.06/2016, namely by the Class I Auction Officer at the Surakarta KPKNL is legally valid. The legal consequences of the Boyolali District Court Decision Number: 64/Pdt.G/2018/PN Byl that the auction of Mortgage executions carried out by Defendant I and Defendant II of the collateral that became collateral for the credit agreement through the Intermediary Office of the State Assets and Auction Service (KPKNL) Surakarta legal. The legal consequence for the Plaintiff is the obligation to pay court fees.

\section{References}

Journals:

[1] Aryo Dharmajaya, 2009, Tinjauan Hukum Terhadap Lelang Atas Tanah dan Bangunan yang Tidak Dapat Dimiliki oleh Pemenang Lelang (Analisis Kasus Putusan Mahkamah Agung Nomor 158k/Pdt/2005), Tesis, Program Pascasarjana, Universitas Indonesia, Jakarta.

[2] Andhyka Muchtar, 2014, Eksistensi dan Kedudukan Kreditur Hak Tanggungan dalam Kepailitan, Jurnal Repertorium, Edisi 2, July-December 2014.

[3] Dwi Nugrohandhin, 2019, Akibat Hukum Gugatan Dan Perlawanan Terhadap Lelang Eksekusi Hak Tanggungan, Jurnal Ilmu hukum, Volume 4, Nomor 1 of 2019. 
[4] Imma Indra Dewi Windajani, 2011, Hambatan Eksekusi Hak Tanggungan di Kantor Pelayanan Kekayaan Negara dan Lelang Yogyakarta, Mimbar Hukum, Special Edition, November 2011.

[5] Maria S.W. Sumardjono, 1997, Kredit Perbankan Permasalahannya Dalam Kaitannya dengan Berlakunya Undang-Undang Hak Tanggungan, Jurnal Hukum (lus Quia lustum), No. 7 Vol. 4 of 1997.

[6] Tri Kurniawan, "Kajian Yuridis Terhadap Parate Eksekusi Objek Jaminan dalam Perjanjian Hak Tanggungan," Jurnal IImu Hukum Legal Opinion, Vol.4 of 2016.

Books:

[1] A.P Parlindungan, 1996, Komentar Undang-Undang Tentang Hak Tanggungan dan Sejarah Terbentuknya, CV. Mandar Maju, Bandung.

[2] Andrian Sutedi, 2010, Hukum Hak Tanggungan, Sinar Grafika, Jakarta.

[3] Bahder Johan Nasution, 2008, Metode Penelitian IImu Hukum, Bandung, Mandar Maju.

[4] Boedi Harsono, 2002, Hukum Agraria Indonesia, Himpunan PeraturanPeraturann Hukum Tanah, Djambatan, Jakarta.

[5] Budi Harsono, 2007, Hukum Agraria Indonesia, (Sejarah Pembentukan, Undang-Undang Pokok Agraria, Isi dan Pelaksanaannya), Djambatan, Jakarta.

[6] C.S.T Kansil dan Christine ST Kansil, 1997, Pokok-Pokok Hukum Hak Tanggungan Atas Tanah, Pustaka Sinar Harapan, Jakarta.

[7] C.S.T Kansil dan Christine ST Kansil, 1997, Pokok-Pokok Hukum Hak Tanggungan Atas Tanah, Pustaka Sinar Harapan, Jakarta.

[8] Cik Hasan Bisri, 1998, Peradilan Agama di Indonesia, Jakarta: PT Raja Grafindo Persada.

[9] Djoni S. Gazali dan Rachmadi Usman, 2012, Hukum Perbankan, ctk. II, Sinar Grafika, Jakarta.

[10] Evi Ariyani, 2013, Hukum Perjanjian, ctk. Pertama, Ombak, Yogyakarta.

[11] FX. Ngadijarno dan Nunung Eko Laksito, Teori dan Praktek Lelang, Modul BPPK Departemen Keuangan RI, http://www. bppk. depkeu.go.id/index.php/lelang-teori-dan-praktek/view-category.html, Diakses Tanggal 11 Oktober 2020, Jam 21.30 WIB.

[12] Habib Adjie, 2000, Hak Tanggungan Sebagai Lembaga Jaminan Atas Tanah, ctk. I, Mandar Maju, Bandung.

[13] Herlien Budiono, B, 2011, Ajaran Umum Hukum Perjanjian dan Penerapannya di Bidang Kenotariatan, Penerbit PT. Citra Aditya Bakti, Bandung.

[14] HR. Daeng Naja, 2005, Hukum Kredit dan Bank Garansi, PT. Citra Aditya Bakti, Bandung.

[15] http://www.pengertianartidefinisi.com/2015/10/pengertianhukum-yuridis/, diakses pada tgl 09 Mei 2021, pukul 14:00 WIB 
[16] I Made Soewandi, 2005, Balai Lelang, Kewenangan Balai Lelang dalam Penjualan Jaminan Kredit Macet, Yayasan Gloria, Yogyakarta.

[17] Ignatius Ridwan, 1996, Hak Tanggungan Atas Tanah, Badan Penerbit Undip, Semarang.

[18] J. Satrio, 2004, Hukum Jaminan Hak Jaminan Kebendaan, Hak Tanggungan, Buku II, PT. Citra Aditya Bakti, Bandung.

[19] Kartini Muljadi-Gunawan Widjaja, 2005, Seri Hukum Perikatan, Perikatan Pada Umumnya, Raja Grafindo Persada, Jakarta.

[20] Kashadi, 2000, Hak Tanggungan dan Jaminan Fidusia, Fakultas Hukum UNDIP, Semarang, hIm. 19.

[21] Lon Fuller dalam tesishukum.com/pengertian-asas-kepastianhukum-menurut-para- ahli/diunduh pukul 11.32 WIB tanggal 15 November 2020

[22] M. Bahsan, 2010, Hukum Jaminan dan Jaminan Kredit Perbankan Indonesia, Cet.ke 3, Raja Grafindo Persada, Jakarta.

[23] M. Khoidin, 2005, Problematika Eksekusi Hak Tanggungan, LaksBang Pressindo, Yogyakarta.

[24] M. Yahya Harahap, 1989, Ruang Lingkup Permasalahan eksekusi dibidang Perdata, Gramedia, Jakarta.

[25] Mariam Darius Badrulzaman, 2009, Kompilasi Hukum Jaminan, CV. Mandar Maju, Bandung.

[26] Muhammas Djumhana, 2000, Hukum Perbankan Di Indonesia, Citra Aditya Bakti, Bandung.

[27] Mulyadi, 1996, Tuntutan Provisionil Dalam Hukum Acara Perdata, Jakarta: Djambatan.

[28] Peter Mahmud Marzuki, 2008, Penelitian Hukum, Kencana Prenada Media Group, Jakarta.

[29] Purnama Tioria Sianturi, 2008, Perlindungan Hukum Terhadap Pembeli Barang Jaminan Tidak Bergerak Melalui Lelang, Penerbit Mandar Maju, Bandung.

[30] R. Subekti dan R. Tjitrosudibio, 1986, Pasal 1338, Kitab Undangundang Hukum Perdata, Pradnya Paramita, Jakarta Pusat.

[31] Rochmat Soemitro, 2000, Dasar-dasar Hukum Pajak dan Pajak Pendapatan, Eresoo, Jakarta.

[32] Salbiah, 2004, Materi Pokok Pengetahuan Lelang, Pusat Pendidikan dan Pelatihan Perpajakan, Jakarta.

[33] Salim HS, 2017, Perkembangan Hukum Jaminan Di Indonesia, Raja Grafindo Persada, Jakarta.

[34] Sudargo Gautama, 1998, Komentar atas Peraturan Kepailitan Baru, Citra Aditya Bakti, Bandung.

[35] Sudikno Mertokusumo, 2002, Hukum Acara Perdata Indonesia, Yogyakarta: Liberty. 
[36] Surayin, 2005, Analisis Kamus Umum Bahasa Indonesia, Bandung, Yrama Widya.

[37] Sutan Remy Sjahdeini, 1999, Hak Tangungan Azas-Azaz Ketentuan-Ketentuan Pokok dan Masalah yang Dihadapi oleh Perbankan, Suatu Kajian Mengenai Undang-Undang Hak Tanggungan, Alumni, Bandung.

[38] Sutarno, 2009, Aspek-Aspek Hukum Perkreditan pada Bank, Alfabeta, Bandung.

[39] Sutiarnoto, 2018, Peraturan Hukum Lelang di Indonesia, Medan, USU Press.

[40] Wirjono Prodjodikoro, 1999, Asas-asas Hukum Perjanjian, Sumur, Bandung.

[41] Yulfasni, 2010, Hukum Kontrak, Magister Kenotariatan Fakultas Hukum Universitas Andalas Padang.

Regulations:

[1] Civil law Code

[2] Act No. 4 of 1996 concerning Mortgage Rights

[3] Act No. 10 of 1998 concerning Banking

[4] Boyolali District Court Decision Number 64/Pdt.G/2018/PN Byl

\title{
The Juridical Study Claims for Cancellation of Insurance Rights Auction Execution
}

\author{
Putri Qoriyati Aeny*) and Arpangi ${ }^{* *}$ \\ $\left.{ }^{*}\right)$ Faculty of Law, Universitas Islam Sultan Agung (UNISSULA) Semarang, E-mail: \\ putriaeny4@gmail.com
}

$\left.{ }^{* *}\right)$ Faculty of Law, Universitas Islam Sultan Agung (UNISSULA) Semarang, E-mail: arpangi@unissula.ac.id

\begin{abstract}
This study aims to examine the issue of the lawsuit for canceling the execution of credit guarantee auctions that are burdened with mortgage rights in the Boyolali District Court Decision Number 64/Pdt.G/2018/PN Byl. Reviewing Judges' Considerations in Deciding Cases on Claims for Cancellation of Execution of Mortgage Auctions. Reviewing the Legal Consequences of Lawsuits for Cancellation of Execution of Mortgage Auctions. This research is a normative juridical research. This research focuses on document or library research which essentially looks for theories, views that have correlation and are relevant to the problems to be studied. The results of the study concluded that the lawsuit for the
\end{abstract}


cancellation of the execution of the credit guarantee auction that was burdened with mortgage rights in the Boyolali District Court Decision Number: 64/Pdt. G/2018/PN Byl, which starts with the provision of Local Credit Facilities (Current Accounts) with a credit limit not exceeding IDR 1,700,000,000.00 (one billion seven hundred million rupiah), based on Credit Agreement No. 125/PK/KRED/SLA/2008 dated October 13, 2008, and has been amended and updated several times, most recently by Amendment to Credit Agreement No. 145/AD/KRED/SLA/2015 dated October 6, 2015, and has been extended several times, most recently with the Notification of Extension of Period No. 145/AD/KRED/SLA/2015. 00118/SLA/SPPJ/2017 dated October 12, 2017. However, during the credit agreement period, the Plaintiff defaulted because he did not make installments every month, so Defendant I had given warning letters 3 times, therefore Defendant I through Defendant II carried out an auction execution of the object of credit guarantee that had been registered with the Mortgage Rights. The judge's consideration in deciding the lawsuit for the cancellation of the execution of the mortgage auction that was burdened with Mortgage was based on the exception of Defendant I and the evidence presented at the trial, which showed that the auction of the execution of the mortgage on the Collateral Object had been carried out in accordance with Article 22 PMK No. 27/PMK.06/2016, namely by the Class I Auction Officer at the Surakarta KPKNL is legally valid. The legal consequences of the Boyolali District Court Decision Number: 64/Pdt. G/2018/PN Byl that the auction of Mortgage Execution conducted by Defendant I and Defendant II of the collateral that is guaranteed by the credit agreement through the Surakarta State Property and Auction Service Intermediary Office (KPKNL) is legal according to law. The legal consequence for the Plaintiff is the obligation to pay court fees.

Keywords: Auction Cancellation Lawsuit; Mortgage Rights; Execution.

\section{Introduction}

The function of the guarantee is to give the bank the right and power to get repayment with the collateral, if the debtor fails to repay the debt at the time specified in the agreement. The implementation of the provision of collateral and the binding of collateral must be in accordance with the provisions of the applicable laws so that it can provide protection through a guarantee rights institution and provide legal certainty for all interested parties. The execution of the debtor's guarantee is a second way out which is the creditor's right to obtain funds that have been distributed to the debtor.

Salim HS argues that: "A guarantee is something given to a creditor to create confidence that the debtor will fulfill obligations that can be valued in money 
arising from an engagement." ${ }^{3}$ The safest credit guarantee is a material guarantee. In accordance with the nature of material rights, these rights are special in that the collateral object is devoted to the interests of the creditor, and material rights also follow the object, so that it can be defended from anyone.

The Law of the Republic of Indonesia Number 4 of 1996 concerning Mortgage Rights on Land and Objects Related to Land, provides a position that is prioritized for creditors holding Mortgage Rights over other creditors. If the debtor is in default, the object of the mortgage by the creditor holding the mortgage is sold through a public auction according to the method specified in the applicable laws and regulations and the creditor who holds the mortgage has the right to take all or part of the proceeds for the settlement of his receivables guaranteed by the mortgage with precedence over other creditors.

Execution of the object of collateral is the exercise of the rights of the creditor holding the collateral right to the object of the guarantee in the event of a denial by the debtor by selling the object of the object of collateral to pay off the debt. Execution is usually carried out if there are receivables that have been collected (opeisbaar) and the debtor does not fulfill its performance voluntarily, here the creditor can demand the fulfillment of his receivables or the right of execution of the object of the material guarantee that he has agreed upon.

The right to fulfill the creditor's rights is carried out by selling the object of the collateral, and the proceeds are used as repayment of the creditor's receivables. Article 6 and Article 20 of Act No. 4 of 1996 concerning Mortgage on Land and Objects Related to Land gives the right to sell the object of Mortgage for reasons of breach of contract, if the debtor is in default, the holder of the mortgage (creditor) has the right to sell the object. Mortgage rights, both based on court decisions and on their own power, the meaning of selling the mortgage object for reasons of default is the same as executing the mortgage object.

Act No. 4 of 1996 concerning Mortgage on Land and Objects Related to Land provides provisions for the convenience and certainty of the execution of Mortgage Rights. However, the provisions of Article 14 of the Regulation of the Minister of Finance of the Republic of Indonesia Number 27/PMK.06/2016 concerning Auction Implementation Guidelines ("PMK Auction Implementation Guidelines") states that the execution auction according to Article 6 of Act No. 4 of 1996 concerning Mortgage on Land Along with Objects Related to Land, it cannot be carried out if there is a lawsuit before the auction against the object of Mortgage from other parties other than the debtor/executed, the husband or wife of the debtor/executed related to ownership.

${ }^{3}$ Salim HS, 2017, Perkembangan Hukum Jaminan Di Indonesia, Raja Grafindo Persada, Jakarta, p. 22 
In exercising the bank's right to the execution of the mortgage object, sometimes the bank faces various problems that can cause the bank's right to sell the mortgage object to be delayed. One of the obstacles faced by banks to execute the object of mortgage is a lawsuit made by the debtor to the bank asking for a delay in the execution of the object of mortgage. This is due to the possibility that there are some debtors who are naughty or feel that the creditor's decision is unfair in carrying out the execution of their land. In this case the creditor really needs legal protection, in order to overcome some of the problems that will arise in the credit agreement from the creditor to the debtor.

Banks as creditors holding mortgage rights have a special position compared to other creditors. This means that when there is a real default from the debtor, the creditor holding the first mortgage has the right to make a sale through a public auction of the object of the debtor's collateral. Sales through auctions of collateral objects must go through the procedural laws and regulations (UUHT). According to ST. Remy Sjahdeini in Tri Kurniawan asserts that according to Article 6 of the UUHT, if the debtor has a pledge, the holder of the first mortgage has the right to sell the object of the mortgage on his own power through a public auction and take repayment of his receivables from the proceeds of the sale. ${ }^{4}$

One option that can be executed is in the form of parate execution as stated in Article 6 of the UUHT. Parate execution in mortgage is an execution without interference from the court but directly asks the State auction office to conduct an auction for the object of mortgage guarantee, to make a decision on the debtor's debt, as happened in the case of auction of collateral goods in Boyolali District Court Decision Number 64/Pdt .G/2018/PN Byl.

This case began with the debtor and creditor entering into a Working Capital Credit Agreement (KMK), namely H. Soejono and Sri Wahyuni as Plaintiffs against PT Bank Central Asia, Tbk Salatiga Branch. 1482, Candi Village, Ampel District, Boyolali Regency, Central Java Province, area +427 M2 (four hundred and twenty-seven square meters). Over time, the debtor has defaulted by not making installment payments, even though a warning letter has been submitted 3 (three) times, the fact is that the Plaintiff as the debtor still does not pay the debt to the Defendant as the creditor, so it is clearly proven that the Plaintiff has no good faith to settle the arrears owed to the Defendant.

Based on the foregoing, the creditor submits an application for an execution auction of the disputed object to the State Property and Auction Service Office (KPKNL) based on Article 6 of Act No. 4 of 1996 concerning Mortgage Rights on

\footnotetext{
${ }^{4}$ Tri Kurniawan, "Kajian Yuridis Terhadap Parate Eksekusi Objek Jaminan dalam Perjanjian Hak Tanggungan," Jurnal Ilmu Hukum Legal Opinion, Vol.4, (2016), p. 3
} 
Land and Objects Related to Land, However, when the execution auction is going to be held, the debtor sues the court on the grounds that the creditor has committed an unlawful act, namely, the debtor assumes that the creditor conducts an execution auction of the object of dispute not through the District Court, thus the creditor feels aggrieved.

\section{Research Methods}

This research method uses a normative juridical approach, data collection using literature study. The specifications used in this study are analytical descriptive which are intended to provide as accurate data as possible about a condition or other symptom and it is hoped that this research can provide a clear description of the Judge's Considerations in Deciding the Case of Cancellation of Execution of Mortgage Auction in Boyolali District Court Decision Number 64 /Pdt.G/2018/PN Byl. The data analysis method was carried out qualitatively and then presented descriptively. Research problems in analysis with legal certainty theory.

\section{Results and Discussion}

\subsection{Situation of Lawsuit for Cancellation of Execution of Credit Guarantee Auction Encumbered with Mortgage in Boyolali District Court Decision Number 64/Pdt.G/2018/PN Byl}

The Plaintiff is the legal holder of the land and house as stated in the Land Book No. Hak Milik. 1482, Candi Village, Ampel District, Boyolali Regency, Central Java Province, area $+427 \mathrm{M} 2$ (four hundred and twenty-seven square meters). $8949 / 1995$ was recorded in the name of the right holder Soejono Bin Mintodiharjo. That the Book of Ownership Land No. 1482, Candi Village, Ampel District, Boyolali Regency, Central Java Province, area of $+427 \mathrm{M} 2$ (four hundred and twenty-seven square meters). $8949 / 1995$ was registered in the name of the right holder Soejono Bin Mintodiharjo, as collateral for the debt by the Plaintiffs at PT BANK CENTRAL ASIA, Tbk. Salatiga Branch.

The Plaintiffs have fulfilled their monthly obligations, namely paying the interest of IDR 5,000,000.00 (five million rupiah) determined by PT BANK CENTRAL ASIA, Tbk. Salatiga Branch. In November 2018 Plaintiff I was summoned and met with employees of PT BANK CENTRAL ASIA, Tbk. Salatiga branch, whose name is and usually called Mrs. ASIH, she warned that Plaintiff I to deposit/install capital in December 2018 of IDR 500,000,000.00 (five hundred million rupiah). On the warning from Mrs. ASIH, Plaintiff I agreed to be paid in installments as determined, namely IDR 500,000,000.00 (five hundred million rupiah) in midDecember 2018. 
That on the advice of Mrs. ASIH, until the lawsuit was filed in the Boyolali District Court, it was not yet due in mid-2018, it turned out that the Plaintiffs received a notification from PT BALAI LELANG TUNJUNGAN, Jl. Woltermonginsidi KM.1 No.1 RT.01 RW. 05 Banjardowo Village, Genuk District, Semarang City, regarding the Pre Auction Process number 0048/S.BLT/SMG/X/2018 dated 16 October 2018.

In the opinion of the Plaintiffs, Defendant II is not authorized to carry out the Notification of the Pre Auction Process, because the auction has been regulated in the Regulation of the Minister of Finance of the Republic of Indonesia Number 106/PMK.06/2013 concerning Amendments to the Regulation of the Minister of Finance Number 93/Pmk.06/2010 concerning Article 19 of the Auction Implementation Instructions has stipulated that the place for the auction must be in the working area or the position of the Class II Auction Officer where the goods are located. In this case, the object of the guarantee is in the Boyolali Regency area. Therefore, PT Balai Auction Tunjungan, is not authorized to make a notification of the Pre Auction Process, and is obliged to refuse bidding applications that are not within its authority.

Defendant III was involved in this case with the intention that the object of the dispute over the land belonging to the Plaintiffs should not be transferred to another party before this case has permanent legal force, this is because there has been a notification of the pre-auction process. Therefore, to guarantee the claim for compensation filed by the Plaintiffs so that the object of the dispute is not transferred to another party, please place a confiscation of collateral (Conservatoir Beslag) on the land of the object of dispute. Whereas because the Plaintiffs' claim is based on legal facts and authentic evidence and cannot be denied, this decision can be implemented first even though other legal remedies are possible.

Based on Article 1365 of the Civil Code, "Every act against the law that causes harm to others, requires other people because of the fault it compensated for the losses incurred" that based on the Article, because the actions of the Defendants have harmed the Plaintiffs and are against the law, the Defendants should jointly and severally pay compensation in cash and cash to the Plaintiffs in the amount of IDR 2,000,000,000.00 (two billion rupiah) with the following details: a. Material compensation to pay for the services of a lawyer IDR $500,000,000.00$, b. Immaterial compensation IDR 1,500,000,000.00. Amount IDR 2,000,000,000.00 (two billion rupiah).

Based on all the descriptions and positas mentioned above, then with all humility the Plaintiffs request that before the Head of the District Court in Boyolali please examine the Plaintiffs' claims before the Boyolali District Court trial and subsequently render the fairest decision as follows: 
h. Granted the claim of the Plaintiffs in their entirety.

i. To declare that Defendant I, Defendant II and Defendant III have committed acts against the law

j. Declare a valid and valuable security confiscation (Beslag Conservatory) to Land with Ownership No. 1482, Candi Village, Ampel District, Boyolali Regency, Central Java Province, area $+427 \mathrm{M} 2$ (four hundred and twentyseven square meters) $8949 / 1995$ was recorded in the name of the right holder Soejono Bin Mintodiharjo, which was carried out by the bailiff of the Boyolali District Court.

k. Sentencing the Defendants to postpone the auction of the collateral for the debt on the Land of Ownership No. 1482, Candi Village, Ampel District, Boyolali Regency, Central Java Province, area + 427 M2 (four hundred and twenty-seven square meters). 8949/1995 registered in the name of the right holder Soejono Bin Mintodiharjo, to PT Bank Central Asia, until the decision of this case has permanent legal force.

I. Sentencing the Defendants jointly and severally to pay compensation in cash and cash to the Plaintiffs in the amount of IDR 2,000,000,000.00 (two billion rupiah) with the following details:

3) Material compensation to pay for the services of a lawyer IDR 500,000,000.00

4)

Immaterial compensation of IDR

$1,500,000,000.00$

Amount IDR 2,000,000,000.00 (two billion rupiah).

$\mathrm{m}$. Stating that the decision in this case can be executed first (uit voerbaar bij voorrad) despite the possibility of an appeal, cassation or verzet or other legal remedies from the Defendant.

n. Punish the Defendant to pay all costs incurred in this case.

Or:

Provide another decision which the Boyolali District Court considers fair, proper and appropriate, in a good trial, based on Pancasila and the laws in force in our country.

Based on the results of the analysis, it can be explained that the lawsuit for the cancellation of the execution of the credit guarantee auction that is burdened with mortgage rights in the Boyolali District Court Decision Number: 64/Pdt.G/2018/PN Byl, namely starting from the provision of Local Credit Facilities (Newspaper Accounts) with a total credit limit does not exceed IDR $1,700,000,000.00$ (one billion seven hundred million rupiah), based on Credit Agreement No. 125/PK/KRED/SLA/2008 dated October 13, 2008 which was made under hand with sufficient stamp duty, and has been amended and updated several times, most recently by Amendment to Credit Agreement No. 
145/AD/KRED/SLA/2015 dated October 6, 2015 which was made under hand with sufficient stamp duty, and has been extended several times, most recently by Notification Letter of Extension of Period No.

The Plaintiffs during the credit agreement period, the Plaintiffs defaulted because they did not make monthly installments, so that Defendant I had given warning letters 3 times, but did not receive a response from the Plaintiffs, therefore Defendant I through Defendant II carried out an auction execution of the object of credit guarantee which has been registered with the Mortgage Rights.

\subsection{Judge's Consideration in Deciding the Case for Cancellation of Execution of Credit Guarantee Auctions Encumbered with Mortgage in Boyolali District Court Decision Number 64/Pdt.G/2018/PN Byl}

Based on the results of the analysis, it can be explained that the Boyolali District Court judge in deciding the case had considered the statements of the Plaintiff and Defendant, which was adjusted to the evidence submitted by the Plaintiff and Defendant. The Panel of Judges concluded that the Plaintiff did not have good faith to pay off his debt, so Defendant I warned the Plaintiff to be able to pay off his debt by sending Warning Letter I (First) dated March 12, 2018 and Warning Letter III (Third) dated May 2 2018, then issued notification letter of pre auction process Number 0048/S.BLT/SMG/X/2018 dated October 16, 2018.

The Panel of Judges is of the opinion that the auction of the execution of mortgage rights on the Collateral Object conducted by Defendant 1 and Defendant II has been carried out in accordance with the provisions of Article 22 PMK No. 27/PMK.06/2016, namely by the Class I Auction Officer at KPKNL Surakarta, as evidenced by the Copy of Minutes of Auction No. 90/38/2019 dated February 12, 2019 published by KPKNL Surakarta.

\subsection{Legal Consequences of Lawsuit for Cancellation of Execution of Credit Guarantee Auctions Encumbered with Mortgage on Boyolali District Court Decision Number 64/Pdt.G/2018/PN Byl}

The legal consequences of the Boyolali District Court Decision Number: 64/Pdt.G/2018/PN Byl which rejected the plaintiff's claim, the legal consequences for the parties are as follows:

\section{c. For Defendant I and Defendant II}

The legal consequence of the Boyolali District Court Decision Number: 64/Pdt.G/2018/PN Byl which rejected the plaintiff's claim, the auction of the execution of mortgage rights against the Collateral Object has been carried 
out in accordance with the provisions of Article 22 PMK No. 27/PMK.06/2016, namely by the Class I Auction Officer at KPKNL Surakarta, as evidenced by the Copy of Minutes of Auction No. 90/38/2019 dated February 12, 2019 published by KPKNL Surakarta. As for Attachment II to the Regulation of the Minister of Finance of the Republic of Indonesia Number 263/PMK.01/2016 concerning Amendments to the Regulation of the Minister of Finance Number 170/PMK.01/2012 concerning the Organization and Work Procedures of Vertical Agencies of the Directorate General of State Assets ("PMK No. 263/ PMK.01/2016"), that the work area of the Surakata KPKNL includes Surakarta City, Boyolali Regency, Karanganyar Regency, Klaten Regency,

Considering the location of the Collateral Object is located in Boyolali Regency, the execution auction of the Collateral Object conducted through the Surakata KPKNL is correct and appropriate according to the division of the KPKNL working area as regulated in PMK No. 263/PMK.01/2016. Thus it is proven that the auction has been carried out in accordance with the provisions of Article 22 of the Regulation of the Minister of Finance PMK No. 27/PMK.06/2016, which states that: "The place for the auction must be within the KPKNL working area or the Class II Auction Officer position where the goods are located." Therefore, the auction is valid and cannot be canceled legally, based on the provisions of Article 4 PMK No. 27/PMK.06/2016 which states: "The auction which has been carried out in accordance with the applicable provisions, cannot be cancelled."

\section{d. For Plaintiffs}

The legal consequences for the plaintiff against the decision of the Boyolali District Court Number: 64/Pdt.G/2018/PN Byl which rejected the plaintiff's claim, that the Plaintiff has an obligation to pay court fees in the amount of IDR3,451,000.00 (three million four hundred five twenty one thousand rupiah).

Based on the results of the analysis, it is shown that the Boyolali District Court Judge rejected the Plaintiffs' lawsuit in its entirety, so that it had a legal impact on the Plaintiffs and Defendants. The legal consequence for the plaintiff is to pay court fees in the amount of IDR3,451,000.00 (three million four hundred fiftyone thousand rupiah). Meanwhile, the legal consequence for the Defendant is the implementation of an auction for the guarantee of the debt on the Land of Ownership No. 1482, Candi Village, Ampel District, Boyolali Regency, Central Java Province, area $+427 \mathrm{M} 2$ (four hundred and twenty-seven square meters). $8949 / 1995$ registered in the name of the right holder Soejono Bin Mintodiharjo, to PT Bank Central Asia is legal according to law. This is considering the location of the Collateral Object is located in Boyolali Regency, then the execution auction 
of the Collateral Object conducted through the Surakata KPKNL is correct and appropriate according to the division of the KPKNL working area as regulated in PMK No. 263/PMK.01/2016.

The auction has been carried out in accordance with the provisions of Article 22 Regulation of the Minister of Finance PMK No. 27/PMK.06/2016, which states that: "The place for the auction must be within the KPKNL working area or the Class II Auction Officer position where the goods are located." Therefore, the auction is valid and cannot be canceled legally, based on the provisions of Article 4 PMK No. 27/PMK.06/2016 which states that: "The auction which has been carried out in accordance with the applicable provisions cannot be cancelled."

\section{Closing}

There is a lawsuit for the cancellation of the execution of credit guarantee auctions that are burdened with mortgage rights in the Boyolali District Court Decision Number: 64/Pdt.G/2018/PN Byl, which begins with the provision of Local Credit Facilities (Current Accounts) with the amount of the credit limit not exceeding IDR 1,700,000,000.00 (one billion seven hundred million rupiah), based on Credit Agreement No. 125/PK/KRED/SLA/2008 dated October 13, 2008 which was made under hand with sufficient stamp duty, and has been amended and updated several times, most recently by Amendment to Credit Agreement No. 145/AD/KRED/SLA/2015 dated October 6, 2015 which was made under hand with sufficient stamp duty, and has been extended several times, most recently by Notification Letter of Extension of Period No. 00118/SLA/SPPJ/2017 dated October 12, 2017. However, during the credit agreement period, The Plaintiff defaulted because it did not make installments every month, so Defendant I had given warning letters 3 times, but did not get a response from the Plaintiff, therefore Defendant I through Defendant II carried out an auction execution of the object of credit guarantee that had been registered with Mortgage. The judge's consideration in deciding the lawsuit for the cancellation of the execution of the credit guarantee auction that was burdened with Mortgage in the Boyolali District Court Decision Number: 64/Pdt.G/2018/PN Byl was based on the exception of Defendant I and the evidence presented at trial, which showed that the auction was conducted the execution of the mortgage on the Collateral Object has been carried out in accordance with the provisions of Article 22 PMK No. 27/PMK.06/2016, namely by the Class I Auction Officer at the Surakarta KPKNL is legally valid. The legal consequences of the Boyolali District Court Decision Number: 64/Pdt.G/2018/PN Byl that the auction of Mortgage executions carried out by Defendant I and Defendant II of the collateral that became collateral for the credit agreement through the Intermediary Office of the State Assets and Auction Service (KPKNL) Surakarta legal. The legal consequence for the Plaintiff is the obligation to pay court fees. 


\section{References}

Journals:

[1] Aryo Dharmajaya, 2009, Tinjauan Hukum Terhadap Lelang Atas Tanah dan Bangunan yang Tidak Dapat Dimiliki oleh Pemenang Lelang (Analisis Kasus Putusan Mahkamah Agung Nomor 158k/Pdt/2005), Tesis, Program Pascasarjana, Universitas Indonesia, Jakarta.

[2] Andhyka Muchtar, 2014, Eksistensi dan Kedudukan Kreditur Hak Tanggungan dalam Kepailitan, Jurnal Repertorium, Edisi 2, July-December 2014.

[3] Dwi Nugrohandhin, 2019, Akibat Hukum Gugatan Dan Perlawanan Terhadap Lelang Eksekusi Hak Tanggungan, Jurnal Ilmu hukum, Volume 4, Nomor 1 of 2019.

[4] Imma Indra Dewi Windajani, 2011, Hambatan Eksekusi Hak Tanggungan di Kantor Pelayanan Kekayaan Negara dan Lelang Yogyakarta, Mimbar Hukum, Special Edition, November 2011.

[5] Maria S.W. Sumardjono, 1997, Kredit Perbankan Permasalahannya Dalam Kaitannya dengan Berlakunya Undang-Undang Hak Tanggungan, Jurnal Hukum (lus Quia lustum), No. 7 Vol. 4 of 1997.

[6] Tri Kurniawan, "Kajian Yuridis Terhadap Parate Eksekusi Objek Jaminan dalam Perjanjian Hak Tanggungan," Jurnal IImu Hukum Legal Opinion, Vol.4 of 2016.

Books:

[1] A.P Parlindungan, 1996, Komentar Undang-Undang Tentang Hak Tanggungan dan Sejarah Terbentuknya, CV. Mandar Maju, Bandung.

[2] Andrian Sutedi, 2010, Hukum Hak Tanggungan, Sinar Grafika, Jakarta.

[3] Bahder Johan Nasution, 2008, Metode Penelitian IImu Hukum, Bandung, Mandar Maju.

[4] Boedi Harsono, 2002, Hukum Agraria Indonesia, Himpunan PeraturanPeraturann Hukum Tanah, Djambatan, Jakarta.

[5] Budi Harsono, 2007, Hukum Agraria Indonesia, (Sejarah Pembentukan, Undang-Undang Pokok Agraria, Isi dan Pelaksanaannya), Djambatan, Jakarta.

[6] C.S.T Kansil dan Christine ST Kansil, 1997, Pokok-Pokok Hukum Hak Tanggungan Atas Tanah, Pustaka Sinar Harapan, Jakarta.

[7] C.S.T Kansil dan Christine ST Kansil, 1997, Pokok-Pokok Hukum Hak Tanggungan Atas Tanah, Pustaka Sinar Harapan, Jakarta.

[8] Cik Hasan Bisri, 1998, Peradilan Agama di Indonesia, Jakarta: PT Raja Grafindo Persada.

[9] Djoni S. Gazali dan Rachmadi Usman, 2012, Hukum Perbankan, ctk. II, Sinar Grafika, Jakarta.

[10] Evi Ariyani, 2013, Hukum Perjanjian, ctk. Pertama, Ombak, Yogyakarta. 
[11] FX. Ngadijarno dan Nunung Eko Laksito, Teori dan Praktek Lelang, Modul BPPK Departemen Keuangan RI, http://www. bppk. depkeu.go.id/index.php/lelang-teori-dan-praktek/view-category.html, Diakses Tanggal 11 Oktober 2020, Jam 21.30 WIB.

[12] Habib Adjie, 2000, Hak Tanggungan Sebagai Lembaga Jaminan Atas Tanah, ctk. I, Mandar Maju, Bandung.

[13] Herlien Budiono, B, 2011, Ajaran Umum Hukum Perjanjian dan Penerapannya di Bidang Kenotariatan, Penerbit PT. Citra Aditya Bakti, Bandung.

[14] HR. Daeng Naja, 2005, Hukum Kredit dan Bank Garansi, PT. Citra Aditya Bakti, Bandung.

[15] http://www.pengertianartidefinisi.com/2015/10/pengertianhukum-yuridis/, diakses pada tgl 09 Mei 2021, pukul 14:00 WIB

[16] I Made Soewandi, 2005, Balai Lelang, Kewenangan Balai Lelang dalam Penjualan Jaminan Kredit Macet, Yayasan Gloria, Yogyakarta.

[17] Ignatius Ridwan, 1996, Hak Tanggungan Atas Tanah, Badan Penerbit Undip, Semarang.

[18] J. Satrio, 2004, Hukum Jaminan Hak Jaminan Kebendaan, Hak Tanggungan, Buku II, PT. Citra Aditya Bakti, Bandung.

[19] Kartini Muljadi-Gunawan Widjaja, 2005, Seri Hukum Perikatan, Perikatan Pada Umumnya, Raja Grafindo Persada, Jakarta.

[20] Kashadi, 2000, Hak Tanggungan dan Jaminan Fidusia, Fakultas Hukum UNDIP, Semarang, hlm. 19.

[21] Lon Fuller dalam tesishukum.com/pengertian-asas-kepastianhukum-menurut-para- ahli/diunduh pukul 11.32 WIB tanggal 15 November 2020

[22] M. Bahsan, 2010, Hukum Jaminan dan Jaminan Kredit Perbankan Indonesia, Cet.ke 3, Raja Grafindo Persada, Jakarta.

[23] M. Khoidin, 2005, Problematika Eksekusi Hak Tanggungan, LaksBang Pressindo, Yogyakarta.

[24] M. Yahya Harahap, 1989, Ruang Lingkup Permasalahan eksekusi dibidang Perdata, Gramedia, Jakarta.

[25] Mariam Darius Badrulzaman, 2009, Kompilasi Hukum Jaminan, CV. Mandar Maju, Bandung.

[26] Muhammas Djumhana, 2000, Hukum Perbankan Di Indonesia, Citra Aditya Bakti, Bandung.

[27] Mulyadi, 1996, Tuntutan Provisionil Dalam Hukum Acara Perdata, Jakarta: Djambatan.

[28] Peter Mahmud Marzuki, 2008, Penelitian Hukum, Kencana Prenada Media Group, Jakarta.

[29] Purnama Tioria Sianturi, 2008, Perlindungan Hukum Terhadap Pembeli Barang Jaminan Tidak Bergerak Melalui Lelang, Penerbit Mandar Maju, Bandung. 
[30] R. Subekti dan R. Tjitrosudibio, 1986, Pasal 1338, Kitab Undangundang Hukum Perdata, Pradnya Paramita, Jakarta Pusat.

[31] Rochmat Soemitro, 2000, Dasar-dasar Hukum Pajak dan Pajak Pendapatan, Eresoo, Jakarta.

[32] Salbiah, 2004, Materi Pokok Pengetahuan Lelang, Pusat Pendidikan dan Pelatihan Perpajakan, Jakarta.

[33] Salim HS, 2017, Perkembangan Hukum Jaminan Di Indonesia, Raja Grafindo Persada, Jakarta.

[34] Sudargo Gautama, 1998, Komentar atas Peraturan Kepailitan Baru, Citra Aditya Bakti, Bandung.

[35] Sudikno Mertokusumo, 2002, Hukum Acara Perdata Indonesia, Yogyakarta: Liberty.

[36] Surayin, 2005, Analisis Kamus Umum Bahasa Indonesia, Bandung, Yrama Widya.

[37] Sutan Remy Sjahdeini, 1999, Hak Tangungan Azas-Azaz Ketentuan-Ketentuan Pokok dan Masalah yang Dihadapi oleh Perbankan, Suatu Kajian Mengenai Undang-Undang Hak Tanggungan, Alumni, Bandung.

[38] Sutarno, 2009, Aspek-Aspek Hukum Perkreditan pada Bank, Alfabeta, Bandung.

[39] Sutiarnoto, 2018, Peraturan Hukum Lelang di Indonesia, Medan, USU Press.

[40] Wirjono Prodjodikoro, 1999, Asas-asas Hukum Perjanjian, Sumur, Bandung.

[41] Yulfasni, 2010, Hukum Kontrak, Magister Kenotariatan Fakultas Hukum Universitas Andalas Padang.

Regulations:

[1] Civil law Code

[2] Act No. 4 of 1996 concerning Mortgage Rights

[3] Act No. 10 of 1998 concerning Banking

[4] Boyolali District Court Decision Number 64/Pdt.G/2018/PN Byl 